\title{
Virus Reduction of Human Plasma-Derived Biological Medicines
}

\author{
Shahnaz Nazari, ${ }^{1}$ Mohammad Ali Jalili, ${ }^{2}$ Majid Shahabi, ${ }^{3}$ Mohammad Fallah Tafti, ${ }^{3}$ Saleh Nasiri, ${ }^{3}$ \\ Mohammad Mouradi, ${ }^{3}$ and Kamran Mousavi Hosseini, ${ }^{3,}$ \\ ${ }^{1}$ Department of Environmental Engineering, Islamic Azad University, Central Tehran Branch, Tehran, Iran \\ ${ }^{2}$ Department of Biochemistry, Blood Transfusion Research Center, High Institute for Research and Education in Transfusion Medicine, Tehran, Iran \\ ${ }^{3}$ Department of Biotechnology, Blood Transfusion Research Center, High Institute for Research and Education in Transfusion Medicine, Tehran, Iran \\ "Corresponding author: Kamran Mousavi Hosseini, Department of Biochemistry, Blood Transfusion Research Center, High Institute for Research and Education in Transfusion \\ Medicine, Tehran, Iran. Tel: +98-2182052160, Fax: +98-2188621845, E-mail: mkmousavi@yahoo.com
}

Received 2016 August 15; Revised 2016 November 29; Accepted 2016 December 26.

\begin{abstract}
Context: Biological plasma-derived medicines play an important role in the treatment and also prevention of many diseases. The technique implemented to produce such medicines should ensure to minimize the risk of pathogen infection. A very crucial step is the removal or inactivation of highly pathogenic plasma viruses, and only achieving the highly pure product is not adequate.

Evidence Acquisition: In the current study, a wide range of physical, chemical, and physicochemical methods of virus inactivation and virus removal were studied to minimize the virus contamination risk in plasma-derived medicines.

Results: The virus removal or virus inactivation procedures showed that they were the quite effective techniques in pathogen reduction. But, some of these methods such as solvent/detergent were only effective on lipid-enveloped viruses, while other techniques can be effective both for lipid-enveloped and non-enveloped viruses.

Conclusions: To inactivate or remove the most range of viruses, at least 2 different virus inactivation or virus removal techniques should be implemented. But, still emerging new pathogens cause a serious challenge in terms of blood safety, and consequently, safety of human plasma-derived medicines.
\end{abstract}

Keywords: Virus Removal, Virus Inactivation, Plasma Product, Pathogen Inactivation

\section{Context}

Biological medicines produced from human plasma are the crucial health service to patients (1-7). The technique that can be implemented to produce human plasmaderived biological drugs should guarantee the reproducible separation of the biological components without any denaturation of the protein or in a form of native state as possible (8-13).

The technology of separating plasma-derived products is still changing to achieve higher safety and efficacy (1417). Among the new techniques to separate human plasmaderived components, still the human plasma fractionation by cold ethanol is the most popular technique to prepare plasma-derived biological drugs (18-21).

The quality of the source material, the level of control during manufacturing and the final control play important role in the safety and efficacy of the products (2224). Although variation in the quality of human plasma source material is caused, to some extent, by variation in donors, it can be much more influenced by the way of processing from the donation to preparation of fresh frozen plasma. Composition of the anti-coagulant, $\mathrm{pH}$ of the coagulant, and the change of $\mathrm{pH}$ during collection and storage, speed of freezing, and storage conditions of the fresh frozen plasma are the variables that may affect the quality of fresh frozen plasma (25-27).

A range of proteins, with clinical efficacy, such as albumin, immunoglobulin, coagulation factors, and fibrinogen can be formulated as pharmaceutical compounds. Apart from different techniques in the production of plasma-derived biological drugs, a very crucial step is the removal or inactivation of highly pathogenic plasma viruses; applying only the purification steps is inadequate to prepare plasma-derived products in terms of viral safety (28).

As viral inactivation or virus removing procedures are introduced in the technique of plasma-derived medicine production, the risk of transfusion-transmitted infections is very small nowadays (29). But, the emergence of new pathogens causes a serious challenge in terms of blood safety. There are 2 major methods of viral processing. One is virus removal and the other is virus inactivation.

\section{Evidence Acquisition}

In the current study, a wide range of physical, chemical, and physicochemical methods of virus inactivation and virus removal were studied to minimize the virus contamination risk in plasma-derived medicines (30). 


\section{Results}

\subsection{Virus Removal}

In virus removing method, all viruses are removed from the sample $(31,32)$. The main technique of virus removing during the production of blood-derived medicines is the virus removal by filtration basically named nanofiltration (33).

\subsubsection{Nanofiltration}

The nanofiltration technology removes viruses by size exclusion. Basically, there are 2 pore sizes as $15 \mathrm{~nm}$ to $35 \mathrm{~nm}$ membrane filters used by this method $(22,34-36)$.

When the filters were used, it was shown that more than 4 to 6 logs of wide range of lipid-enveloped viruses and non-enveloped viruses such as hepatitis A virus (HAV) and parvo virus B19 were removed. It was also shown that nanofiltration by $35 \mathrm{~nm}$ (or less) filter removed Creutzfeldt-Jakob disease (CJD). When the protein solution was filtered through a $15-\mathrm{nm}$ membrane filter, the virus removal was almost complete by the reduction of 6-log; and by $35 \mathrm{~nm}$ filtration, only the removal of viruses by 4.5-log was possible (37).

Always harsh conditions may affect the nature of protein, but one of the advantages of this method of virus removal is that it can be performed under mild conditions and the biological activity of the protein remains intact (38). Another advantage of this method is adding no chemicals to the solution (39). Therefore, there is no need to segregate chemicals after nanofiltration and the most important point is the commercial availability of the filters and no need for royalty payment.

Typically, the size of parvovirus can vary from 15 to 24 $\mathrm{nm}$ and it is resistant to virus inactivation and a suitable method to remove it is nanofiltration. Also, nanofiltration method can be implemented in the procedure of most of the plasma-derived biological medicines, but it is mostly used in coagulation factor IX, and in less extent in coagulation factor VIII, and immunoglobulin production (40).

\subsection{Virus Inactivation}

Although blood screening should be conducted for each donation, due to the possibility of viral infection, tests should be carried out for each donation to detect the viral markers including antibodies against human immunodeficiency virus 1 (anti-HIV-1), antibodies against human immunodeficiency virus 2 (anti-HIV-2), hepatitis B surface antigen (HBs Ag), antibodies against hepatitis C virus (anti$\mathrm{HCV}$ ), and based on domestic regulations, the test for alanine aminotransferase (ALT) should also be done.

All these tests and validated freezing storage conditions for plasma to ensure the homogenous quality of plasma is maintained to recover proteins labile in plasma (41) plus virus inactivation methods, which should be implemented in plasma fractionation, make the plasma an expensive raw material that its costs account for around $45 \%$ in the human plasma industry, compared with $5 \%$ in the pharmaceutical industry. The costs for high-quality plasma have risen about $40 \%$ and nucleic acid testing alone adds US\$ 5 to 15 per liter of plasma.

Virus inactivation methods can be carried out in 3 ways: chemical methods, physical methods, and physicochemical methods.

\subsubsection{Physical Methods}

Physical virus inactivation methods are based on heat treatment, which include pasteurization, dry heat treatment, and steam heat treatment.

\subsubsection{Pasteurization}

Virus inactivation by the pasteurization procedure is very effective. It should be noticed that the protein in the solution should be more thermally resistant than viruses. The advantages of this procedure are that it needs simple equipment and is effective both for lipid-enveloped and non-enveloped viruses. Table 1 shows the potency of pasteurization in virus inactivation of plasma.

Table 1. Human Plasma Virus Inactivation by Pasteurization

\begin{tabular}{lc}
\hline Virus & Inactivation $\left(\log _{10}\right)$ \\
\hline Human immunodeficiency virus-1 & $\geq 5.0$ \\
Vaccinia & $\geq 4.3$ \\
\hline Pseudorabies & $\geq 4.1$ \\
\hline Parainfluenza type 3 & $\geq 6.3$ \\
\hline Sindbis & $\geq 5.7$ \\
Poliovirus Sabin 1 & $\geq 6.2$ \\
\hline Reovirus & 3.2 \\
\hline
\end{tabular}

By pasteurization, the temperature of protein solution is increased to a value that sufficiently denatures the virus; therefore, it is effective both for lipid-enveloped and non-enveloped viruses, because the temperature is high enough not to let the envelope protect the virus. By pasteurization, the liquid protein undergoes heat treatment for 10 hours at $60^{\circ} \mathrm{C}(42)$. If the purified protein is not heat resistant, pasteurization for this kind of protein is performed in the presence of stabilizers added to skip protein denaturation $(43,44)$.

Salts such as $\mathrm{NaCl}$ and $\mathrm{CaCl}_{2}$ were effective to inhibit heat-induced aggregation in human albumin. Sodium octanoate and sodium-N-acetyl-DL-tryptophanate are the sta- 
bilizers that minimize changes in the protein during pasteurization of albumin solution (44). The mechanisms of their stabilization on albumin are not fully elucidated; however, it is shown that the stability of proteins against heat stress can be increased by the stabilizers that increase the melting temperature of the proteins.

As a viral reduction treatment, pasteurization is currently applied for therapeutic concentrate including albumin, IM and IV IgG, fibrinogen, thrombin, factor VII, factor VIII, factor IX, factor XI, prothrombin complex concentrate (PCC), von Willebrand factor (vWF), antithrombin III, C1-inhibitor, and protein C (45-47).

Pasteurization is quite effective for viral reduction of both lipid-enveloped and non-enveloped viruses including hepatitis B virus (HBV), hepatitis C virus (HCV), HIV, and HAV. Good record of safety of albumin is a good example of the confidence in the efficacy of pasteurization.

\subsubsection{Dry Heat Treatment}

One of the physical methods of virus inactivation, which can be applied to biopharmaceutical products, is dry heat treatment. Duration of dry heat treatment can be varied from several minutes to several days. The temperature varies from $60^{\circ} \mathrm{C}$ to $100^{\circ} \mathrm{C}$. Table 2 shows the sever heat treatment of coagulation factor VIII at $80^{\circ} \mathrm{C}$ for 72 hours $(48,49)$.

Table 2. Sever Heat Treatment of Coagulation Factor VIII at $80^{\circ} \mathrm{C}$ for 72 Hours

\begin{tabular}{lcc}
\hline Virus & Inactivation $\left(\log _{10}\right)$ & Duration, hr \\
\hline Sindbis virus & 8 & 72 \\
HIV & $\geq 6.4$ & 72 \\
\hline Vaccinia virus & $2.6-3.3$ & 72 \\
\hline Herpes simplex virus & 2.2 & 48 \\
\hline Semliki forest virus & $\geq 6.9$ & 24 \\
HAV & $\geq 4.3$ & 24 \\
\hline Canine parvovirus & $\geq 2.1$ & 48 \\
\hline
\end{tabular}

Kim et al., studied the effect of dry-heat treatment on the activity of coagulation factor VIII. In their experiment, the lyophilized final products were equilibrated at $30^{\circ} \mathrm{C}$. Then, the dry heat treatment was processed at $60^{\circ} \mathrm{C}, 80^{\circ} \mathrm{C}$, and $100^{\circ} \mathrm{C}$. Their investigation on virucidal efficacy of the dry heat treatment showed significant reduction of viruses including HIV, encephalomyocarditis virus (EMCV), bovine viral diarrhea virus (BVDV), and bovine herpes virus (BHV) (50).

Usually, dry heat treatment is applied to the products in their final vials following the lyophilization (51). The common temperature for dry heat treatment is $60^{\circ} \mathrm{C}$ to $68^{\circ} \mathrm{C}$ for up to 72 or 96 hours. This range of temperature is quite effective for the inactivation of HIV, but to inactivate $\mathrm{HBV}$ and $\mathrm{HCV}$, higher temperature of $80^{\circ} \mathrm{C}$ for 3 days is needed (52-54). But, under the severe conditions, still parvovirus B19 is not totally eliminated. As mentioned before, still the best method to eliminate parvovirus B19 is the nanofiltration (55).

Due to the lower humidity in dry heat treatment than pasteurization, the efficacy is lower in dry heat. One of the main advantages of dry heat treatment is avoiding the risk of down-stream contamination, because the heat treatment is carried on the final products. Using simple equipment is another advantage of this method.

Common stabilizers used during dry heat treatment include limited amount of sucrose or amino acids such as glycine, lysine, or arginine.

Validation of dry heat treatment is a paramount importance to ensure the precise temperature control and to indicate that suitable log reduction of viruses is guaranteed by spiking model viruses to sample.

\subsubsection{Steam Heat Treatment}

There are 2 subclasses of viruses, lipid-enveloped and non-enveloped viruses. Lipid-enveloped viruses are highly susceptible to both physical and chemical virus inactivation methods. But, non-enveloped viruses are more resistant. Viral sensitivity is higher to steam heat treatment than dry heat treatment. In other words, at equal temperatures, a higher level of virus inactivation can be obtained by the addition of water steam before starting the heat.

There are 3 key parameters in steam heat treatment including temperature, pressure, and the duration of heating. Generally, the pressure varies from 1190 to $1375 \mathrm{mbar}$, heating temperature varies from $60^{\circ} \mathrm{C}$ to $80^{\circ} \mathrm{C}$, and the duration of heating can be up to 10 hours. Table 3 shows the coagulation factors of virus inactivation by steam heat treatment at $60^{\circ} \mathrm{C}$ for 10 hours $(56,57)$.

It should be noticed that more than 5 -log reduction in the titer of virus indicates that the virus inactivation method is effective. It is noteworthy that some biological products are heated at $60^{\circ} \mathrm{C}$ for 10 hours, while others are additionally heated at $80^{\circ} \mathrm{C}$ for 1 hour. Although steam heat treatment can inactivate HAV in plasma products, some historical reports showed cases of transmission of enveloped virus such as HCV in coagulation factor.

\subsubsection{Chemical Methods}

There are 2 main chemical methods of viral reduction treatments applied to plasma products. One is the solvent/detergent (S/D) and the other is acid $\mathrm{pH}$ incubation at low $\mathrm{pH}$ of $4(58,59)$. Solvent/detergent method is excellent to inactivate lipid-enveloped viruses, and acid $\mathrm{pH}$ 
Table 3. Steam Heat Treatment Virus Inactivation of Coagulation Factors at $60^{\circ} \mathrm{C}$ for 10 Hours

\begin{tabular}{|c|c|c|c|}
\hline Product & Virus & Extent of Inactivation $\left(\log \mathrm{ID}_{50}\right)$ & Inactivation Time (Required Hours) \\
\hline \multirow{3}{*}{ Factor VIII: Intermediate purity } & HAV & $>3.3$ & 8 \\
\hline & HIV & $>6.8$ & 10 \\
\hline & PRV & 5.9 & 10 \\
\hline \multirow{3}{*}{ Factor VIII: High purity } & HAV & 3.9 & 10 \\
\hline & HIV & 6.7 & 10 \\
\hline & PRV & 5.6 & 10 \\
\hline \multirow{3}{*}{ Factor IX: Intermediate purity } & HAV & $>5.7$ & 6 \\
\hline & HIV & $>6.5$ & 6 \\
\hline & PRV & $>7.1$ & 8 \\
\hline \multirow{3}{*}{ Factor IX: Intermediate purity } & HAV & $>6.7$ & 3 \\
\hline & HIV & $>7.9$ & 8 \\
\hline & PRV & $>6.8$ & 8 \\
\hline
\end{tabular}

incubation method is also mostly effective against lipidenveloped, but non-enveloped viruses are more resistant to this method.

\subsubsection{Solvent/Detergent}

The solvent/detergent method is quite potentially effective to inactivate lipid-enveloped viruses and they are killed only in a few minutes (60-62). This method is not effective for non-enveloped viruses and it is one of the main limitations of this method, while removing the solvent and the detergent after $\mathrm{S} / \mathrm{D}$ treatment may cause some protein loss, which is a key challenge of solvent/detergent virus inactivation method. S/D virus inactivation method was developed by the New York blood center.

The organic solvent used in this method is tri-n-butyl phosphate (Figure 1) at the concentration of $0.3 \%$ and the detergent may vary from Tween 80, or Triton X100 to sodium cholate (Figure 2). The concentration of detergent may be about $1 \%$.

By this method the plasma protein solution is incubated at $24^{\circ} \mathrm{C}$ to $30^{\circ} \mathrm{C}$ in the presence of tri-n-butyl phosphate and detergent. The duration of incubation is about 6 hours with mild stirring (63-65).

Removal of organic solvent and the necessary detergent is quite possible by chromatographic, or precipitation and also extraction by soya bean oil techniques (66, 67).

The advantages of S/D treatment of human plasma products in the inactivation of lipid-enveloped viruses are as follows: maintaining biological activity of the plasma derived-products, no neoantigen formation, ease of control, and convenience of implementation. Table 4 shows

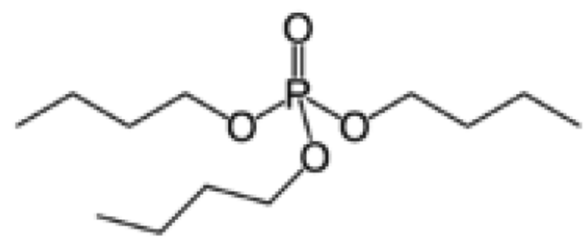

Figure 1. Tri-n-Butyl Phosphate Chemical Structure

the potency of S/D treatment in virus inactivation (68). As this method disrupts the lipid membrane of lipidenveloped viruses, the main limitation of this method is its ineffectiveness for non-enveloped viruses.

Table 4. Inactivation of Lipid-enveloped Viruses by Solvent/Detergent Treatment

\begin{tabular}{|lcc}
\hline Type of Virus & Inactivation $\left(\log _{10}\right)$ & Duration, $\mathbf{h r}$ \\
\hline Vesicular stomatitis virus & $\geq 7.5$ & 0.25 \\
\hline Sindbis virus & $\geq 6.9$ & 0.25 \\
\hline Duck hepatitis B virus & $\geq 7.3$ & 2.5 \\
\hline Bovine viral diarrhea virus & $\geq 6.1$ & 0.25 \\
\hline Human immunodeficiency & $\geq 7.2$ & 0.25 \\
virus & $\geq 6.0$ & \\
\hline Hepatitis B virus & $\geq 5.0$ & 4 \\
\hline Hepatitis C virus & & 4 \\
\hline
\end{tabular}




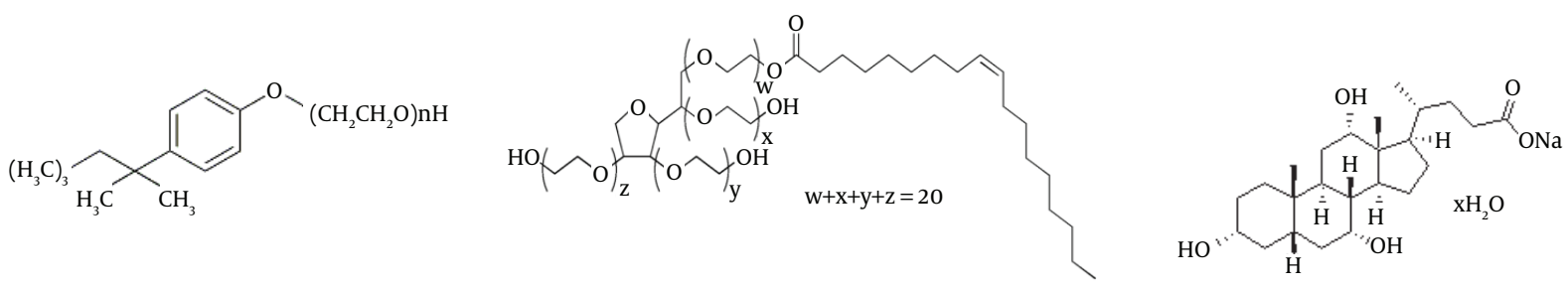

Triton X100 $(\mathrm{n}=9-10)$

Tween 80

Sodium Cholate

Figure 2. Chemical Structure of Detergents Triton X100, Tween 80, and Sodium Cholate

\subsubsection{Incubation in Acidic $\mathrm{pH}$}

Lipid-enveloped viruses denature when expose to acidic $\mathrm{pH}$; therefore, $\mathrm{pH}$ incubation method, similar to S/D treatment, is effective for lipid-enveloped viruses. The key point in this method is the higher sensitivity of target protein to lower $\mathrm{pH}$ values than the virus. Low $\mathrm{pH}$ may denature the target protein as well (69).

Somehow, the process of preparation of some of the plasma-derived products may apply such a condition that is effective as a viral reduction step. For example, when preparing immunoglobulin $\mathrm{G}$, to avoid the side effects of anti-complementary activity, one of the processing steps is the treatment at $\mathrm{pH} 4$ with the presence of pepsin. It is proved that this treatment at acidic $\mathrm{pH} 4$ is quite effective as a viral inactivation step for lipid-enveloped viruses $(70,71)$. The potency of this method for lipid-enveloped virus inactivation ranges from 5 to $8 \log _{10}$ reduction. Nonenveloped viruses are more resistant to viral inactivation by this method. The duration of incubation in acidic $\mathrm{pH}$ may be 20 hours or more, and the temperature may vary from $30^{\circ} \mathrm{C}$ to $37^{\circ} \mathrm{C}$.

\subsubsection{Physicochemical Methods}

\subsubsection{Beta-Propiolactone with/without Irradiation}

By this method of viral inactivation, firs the solution of protein is incubated with beta-propiolactone at a specific wavelength of ultraviolet (UV) light irradiated (72). Validation study indicated that this method was efficient against HIV, HBV, and HAV. The limitation of this method was losing biological activity, especially for labile proteins such as coagulation factor VIII. Therefore, this technique is not suitable for virus inactivation of F VIII.

Also, beta-propiolactone can be used without irradiation. In some procedures of immunoglobulin $\mathrm{G}$ preparation, it is treated with beta-propiolactone. This betapropiolactone treatment shows the potency of viral reduction. The extension of this viral reduction is about $3.5 \log _{10}$ for HCV and $4.5 \log _{10}$ for HIV.

\subsubsection{Methylene Blue and Visible Light}

In this method of viral inactivation, there are parameters, which may affect the result; for instance, the volume of sample, the light intensity, the transparency of the bag of plasma, and mixing efficiency of methylene blue. The methylene blue compound is a photosensitizer, which can disrupt the biological systems in combination with light and presence of oxygen $(73,74)$. By this procedure, plasma units are treated with methylene blue and white fluorescent light for 1 hour or with sodium lamps for 20 minutes.

Methylene blue + light is an effective virus inactivation method for lipid-enveloped viruses, but not effective for non-enveloped viruses (75). Table 5 shows the efficacy of this technique $(76,77)$.

Table 5. Virus Inactivation by Methylene Blue and Light

\begin{tabular}{lcc}
\hline Virus & Inactivation $\left(\log _{10}\right)$ & Duration, $\mathbf{m i n}$ \\
\hline Vesicular stomatitis virus & 5.0 & 60 \\
\hline Semliki forest virus & $\geq 7.0$ & 10 \\
\hline Herpes simplex virus & $\geq 5.5$ & 60 \\
\hline Bovine viral diarrhea & $\geq 5.9$ & 2 \\
\hline Duck hepatitis B virus & 3.9 & 60 \\
\hline Hepatitis A virus & 0 & 60 \\
\hline Porcine parvovirus & 0 & 60 \\
\hline
\end{tabular}

\subsubsection{Neutralization by Antibodies}

Some of the antibodies are capable of neutralizing viruses (78). A good number of antibodies are available in pooled plasma, and that is why non-virally inactivated intramuscular or intravenous immunoglobulin preparations showed no contamination of viruses such as HBV, HAV, or parvovirus B19. But, nowadays by introducing many effective virus inactivation methods, neutralizing by antibodies are less implement. 


\section{Conclusions}

Up to now, there is no virus inactivation method to ensure $100 \%$ inactivation of known plasma-borne viruses such as parvovirus B19, HAV, HBV, HCV, and HIV. To make sure that optimal viral safety level of plasma product is achieved; 2 different viral inactivation techniques should be implemented.

Implementation of the first specific viral inactivation method, that is S/D method, should ensure complete removal of major viruses such as HBV, HCV, and HIV. Use of the second virus reduction technique such as dry heat treatment or nanofiltration, should ensure elimination of other potential infectious agents.

Careful selection and elimination of donors susceptible to known viruses such as HAV, HBV, HCV, and HIV or emerging infectious agents, influence the viral safety of the plasma-derived biological medicines. Another parameter, which may influence the viral safety of plasma-derived drugs, is the refined viral testing procedure of each donation eliminate, within the sensitivity limit of the test used.

Although implementation of interventional virus inactivation methods in the process of biological plasmaderived medicines dramatically reduced the risk of contamination of such products, nowadays most of the residual transfusion-transmitted infections are due to the result of the interval between the time donor is infected and the real time that the tests are capable of detecting the agent and that is because of "window period".

To achieve the high level of safety, researchers are still looking for more effective procedures of virus inactivation or reduction techniques $(79,80)$, and they are also searching for the new diagnostic kits to make the "window period" shorter.

\section{Acknowledgments}

The authors are thankful to the blood transfusion research center, high institute for research and education in transfusion Medicine, Tehran, Iran, for their support.

\section{Footnote}

Funding/Support: The study was financially supported by the blood transfusion research center, high institute for research and education in transfusion Medicine, Tehran, Iran.

\section{References}

1. Farcet MR, Lackner C, Antoine G, Rabel PO, Wieser A, Flicker A, et al. Hepatitis E virus and the safety of plasma products: investigations into the reduction capacity of manufacturing processes. Transfusion. 2016;56(2):383-91. doi: 10.1111/trf.13343. [PubMed: 26399175].

2. Benjamin RJ, McLaughlin LS. Plasma components: properties, differences, and uses. Transfusion. 2012;52 Suppl 1:9S-19S. doi: 10.1111/j.15372995.2012.03622.x. [PubMed: 22578375].

3. Schneider T. [Therapeutic plasmas]. Transfus Clin Biol. 2012;19(45):148-9. doi: 10.1016/j.tracli.2012.07.006. [PubMed: 22999855].

4. Mousavi Hosseini K, Nasiri S. Preparation of factor VII concentrate using CNBr-activated Sepharose 4B immunoaffinity chromatography. Med J Islam Repub Iran. 2015;29:170. [PubMed: 26034723].

5. Mousavi Hosseini K, Nikougoftar Zarif M. Preparation of plasminogen by affinity chromatography. Iran J Blood Cancer. 2014;6(4):163-7.

6. Mousavi Hosseini K, Pourmokhtar M, Dinar Vand R, Rezvan H, Jalili MA. Preparation of enriched immunoglobulin $M$ and immunoglobulin A from human plasma. Med J Islam Repub Iran. 2004;17(4):315-8.

7. Yari F, Mousavi Hosseini K. Simultaneous purification and polymerization method for bovine serum albumin preparation. Ital J Biochem. 2007;56(2):163-5. [PubMed: 17722658].

8. Lozano M, Cid J. Pathogen inactivation: coming of age. Curr Opin Hematol. 2013;20(6):540-5. doi: 10.1097/MOH.ob013e328365a18f. [PubMed: 24104416].

9. Mousavi Hosseini K, Pourmokhtar M, Habibi Roudkenar M, Shahabi $M$. Human plasma derived drugs separation by fractionation of plasmawith polyethylene glycol. Iran J Biotechnol. 2014;12(3):82-5. doi: 10.15171/ijb.1018.

10. Clement S. [Techniques of preparation and indications of labile blood products]. Transfus Clin Biol. 2011;8(2):250-61. doi: 10.1016/j.tracli.2011.02.022. [PubMed: 21474355].

11. Mousavi Hosseini MK, Pourmokhtar M, Jalili MA, Nasiri S. Immunoglobulin A preparation from human pooled plasma using plasma fractionation and ion exchange chromatography. Iran J Blood Cancer. 2014;6(2):75-9.

12. Morgenthaler JJ. New developments in plasma fractionation and virus inactivation. Vox Sang. 2000;78 Suppl 2:217-21. [PubMed: 10938956].

13. Nasiri S, Mousavi Hosseini K. Effects of centrifugation speed on platelet aggregation activity [In Persian]. Koomesh. 2014;15(2):250-4.

14. Roberts PL. Virus elimination during the recycling of chromatographic columns used during the manufacture of coagulation factors. Biologicals. 2014;42(4):184-90. doi: 10.1016/j.biologicals.2014.06.003. [PubMed: 24981392].

15. Rezvan H, Motallebi Z, Jalili MA, Mousavi Hosseini K, Pourfathollah AA. Safety of blood and plasma derivatives: pathogen reducing technologies. Med J Islam Repub Iran. 2006;20(2):86-92.

16. Nasiri S, Mousavi Hosseini MK. Infusible platelet membrane versus conventional platelet concentrate: benefits and disadvantages. Iran J Blood Cancer. 2014;6(2):87-93.

17. Sauvage V, Eloit M. Viral metagenomics and blood safety. Transfus Clin Biol. 2016;23(1):28-38. doi: 10.1016/j.tracli.2015.12.002. [PubMed: 26778104].

18. Klamroth R, Groner A, Simon TL. Pathogen inactivation and removal methods for plasma-derived clotting factor concentrates. Transfusion. 2014;54(5):1406-17. doi: 10.1111/trf.12423. [PubMed: 24117799].

19. Mousavi Hosseini K, Nasiri S, Heidari M. Using ethanol and low temperature in separation of albumin from human plasma. JZanjan Univ Med Sci Health Serv. 2013;21(85):65-7.

20. Mousavi Hosseini K, Heidari M, Yari F. The preparation of albumin as a biological drug from human plasma by fiber filtration [In Persian]. Tehran Univ Med J. 2011;69(5):283-8.

21. Belousova IM, Kislyakov IM, Muraviova TD, Starodubtsev AM, Kris'ko TK, Selivanov EA, et al. Photodynamic inactivation of enveloped virus in protein plasma preparations by solid-phase fullerene-based photosensitizer. Photodiagnosis Photodyn Ther. 2014;11(2):165-70. doi: 10.1016/j.pdpdt.2014.02.009. [PubMed: 24583281] 
22. Mahmoodian Shooshtari M, Mousavi Hosseini K. Evaluation of the plasma quality after filtration. Daru. 2010;18(2):114-7. [PubMed: 22615604].

23. Mousavi Hosseini K, Sharifi Z. Quality assurance and Good Manufacturing Practice in respect of plasma fractionation. I J Blood Cancer 2011;3(3):139-46.

24. Rubsamen-Waigmann H. [Virus inactivation of plasma products. Practical methods and their safety]. Dtsch Med Wochenschr. 1994;119(10):345-8. doi: 10.1055/s-2008-1058701. [PubMed: 8125038].

25. Wigginton KR, Pecson BM, Sigstam T, Bosshard F, Kohn T. Virus inactivation mechanisms: impact of disinfectants on virus function and structural integrity. Environ Sci Technol. 2012;46(21):12069-78. doi: 10.1021/es3029473. [PubMed: 23098102].

26. Jilma-Stohlawetz P, Kursten FW, Horvath M, Leitner G, List J, Marcek $J$, et al. Recovery, safety, and tolerability of a solvent/detergenttreated and prion-safeguarded transfusion plasma in a randomized, crossover, clinical trial in healthy volunteers. Transfusion. 2013;53(9):1906-17. doi:10.1111/trf.12075. [PubMed: 23320451].

27. Mousavi Hosseini K, Jalili MA. Synthesis of vitamin e novel analogues as anti-cancer compounds. Jundishapur J Nat Pharm Prod. 2016;11(1) doi: 10.17795/jjnpp-32350.

28. Kreil TR, Berting A, Kistner O, Kindermann J. West Nile virus and the safety of plasma derivatives: verification of high safety margins, and the validity of predictions based on model virus data. Transfusion. 2003;43(8):1023-8. doi: 10.1046/j.1537-2995.2003.00496.x. [PubMed: 12869106].

29. Burnouf $T$, Radosevich M. Reducing the risk of infection from plasma products: specific preventative strategies. Blood Rev. 2000;14(2):94110. doi: 10.1054/blre.2000.0129. [PubMed: 11012252].

30. Sheffield WP, Bhakta V, Talbot K, Pryzdial EL, Jenkins C. Quality of frozen transfusable plasma prepared from whole blood donations in Canada: an update. Transfus Apher Sci. 2013;49(3):440-6. doi: 10.1016/j.transci.2013.06.012. [PubMed: 23849252].

31. Stuhler A, Blumel J. [Viral safety of biological medicinal products] Bundesgesundheitsblatt Gesundheitsforschung Gesundheitsschutz. 2014;57(10):1198-202. doi: 10.1007/s00103-014-2030-4. [PubMed 25123140].

32. Wieser A, Berting A, Medek C, Poelsler G, Kreil TR, Global Pathogen Safety B. Virus Filtration and Flow Variation: An Approach To Evaluate Any Potential Impact on Virus Retention. PDA J Pharm Sci Technol. 2016;70(4):325-31. doi: 10.5731/pdajpst.2015.006346. [PubMed 27020648].

33. Yokoyama T, Murai K, Murozuka T, Wakisaka A, Tanifuji M, Fujii N, et al. Removal of small non-enveloped viruses by nanofiltration. Vox Sang. 2004;86(4):225-9. doi: 10.1111/j.0042-9007.2004.00515.x. [PubMed: 15144526].

34. Koenderman AH, ter Hart HG, Prins-de Nijs IM, Bloem J, Stoffers S, Kempers A, et al. Virus safety of plasma products using $20 \mathrm{~nm}$ instead of $15 \mathrm{~nm}$ filtration as virus removing step. Biologicals. 2012;40(6):47381. doi: 10.1016/j.biologicals.2012.07.010. [PubMed: 22901944].

35. Furuya K, Murai K, Yokoyama T, Maeno H, Takeda Y, Murozuka T, et al. Implementation of a $20-\mathrm{nm}$ pore-size filter in the plasma-derived factor VIII manufacturing process. Vox Sang. 2006;91(2):119-25. doi 10.1111/j.1423-0410.2006.00792.x. [PubMed: 16907872].

36. Kashef N, Behzadian-Nejad Q, Najar-Peerayen S, Mousavi-Hosseini K Moazeni M, Rezvan $\mathrm{H}$, et al. Preliminary investigation on the isolation of alginate produced by mucoid Pseudomonas aeruginosa. Ann Microbiol. 2005;55(4):279-82.

37. Yunoki M, Yamamoto S, Tanaka H, Nishigaki H, Tanaka Y, Nishida A, et al. Extent of hepatitis E virus elimination is affected by stabilizers present in plasma products and pore size of nanofilters. Vox Sang. 2008;95(2):94-100. doi: 10.1111/j.1423-0410.2008.01078.x. [PubMed: 18714441].

38. Caballero S, Diez JM, Belda FJ, Otegui M, Herring S, Roth NJ, et al. Robustness of nanofiltration for increasing the viral safety margin of biological products. Biologicals. 2014;42(2):79-85. doi: 10.1016/j.biologicals.2013.10.003. [PubMed: 24485384].

39. Cardone F, Simoneau S, Arzel A, Puopolo M, Berardi VA, AbdelHaq $\mathrm{H}$, et al. Comparison of nanofiltration efficacy in reducing infectivity of centrifuged versus ultracentrifuged $263 \mathrm{~K}$ scrapieinfected brain homogenates in "spiked" albumin solutions. Transfusion. 2012;52(5):953-62. doi: 10.1111/j.1537-2995.2011.03425.x. [PubMed: 22082124].

40. Menconi MC, Maggi F, Zakrzewska K, Salotti V, Giovacchini P, Farina $\mathrm{C}$, et al. Effectiveness of nanofiltration in removing small nonenveloped viruses from three different plasma-derived products. Transfus Med. 2009;19(4):213-7. doi: 10.1111/j.1365-3148.2009.00931.x. [PubMed: 19706139].

41. Madani TA, Abuelzein el TM, Azhar EI,Al-Bar HM. Thermal inactivation of Alkhumra hemorrhagic fever virus. Arch Virol. 2014;159(10):2687-91. doi: 10.1007/s00705-014-2134-z. [PubMed: 24906524]

42. Hewitt J, Greening GE. Effect of heat treatment on hepatitis A virus and norovirus in New Zealand greenshell mussels (Perna canaliculus) by quantitative real-time reverse transcription PCR and cell culture. J Food Prot. 2006;69(9):2217-23. doi: 10.4315/0362-028X-69.9.2217. [PubMed: 16995527].

43. Mousavi Hosseini K, Rezvan H, Motalleb Z, Chabokpey S, Mirbod V. Study of the heat-treated human albumin stabilization by caprylate and acetyltryptophanate. Iran Biomed J. 2002;6(4):135-40.

44. Lin JJ, Meyer JD, Carpenter JF, Manning MC. Aggregation of human serum albumin during a thermal viral inactivation step. Int J Biol Macromol. 2009;45(2):91-6. doi: 10.1016/j.ijbiomac.2009.04.017. [PubMed: 19409925].

45. Mousavi Hosseini K, Dinarvand R, Pourmokhtar M, Rezvan $\mathrm{H}$, Jalil MA. Pasteurization of IgM-enriched immunoglobulin. DARU. 2004;12(1):40-3.

46. Rezvan. H. , Nasiri S, Mousavi Hosseini K. Inactivation of polio-virus type-1 and HSV-1 in human coagulation factor VII concentrate by pasteurization. Arch Iran Med. 2001;4(1):10-3.

47. Jalili MA, Hosseini KM. New synthesis of aminorhodanin and condensed derivatives. Pak J Pharm Sci. 2009;22(1):53-7. [PubMed: 19168421].

48. Knevelman A, de Wit HJ, Potstra P, vd Does JA. Development and small-scale production of a severely heated factor VIII concentrate. Vox Sang. 1994;66(2):89-95. doi: 10.1111/j.1423-0410.1994.tb00288.x. [PubMed: 8184598]

49. Winkelman L, Feldman PA, Evans DR. Severe heat treatment of lyophilised coagulation factors. Curr Stud Hematol Blood Transfus. 1989(56):55-69. doi: 10.1159/000416557. [PubMed: 2491985].

50. Kim IS, Choi YW, Kang Y, Sung HM, Shin JS. Dry-heat treatment process for enhancing viral safety of an antihemophilic factor VIII concentrate prepared from human plasma. J Microbiol Biotechnol. 2008;18(5):997-1003. [PubMed: 18633304].

51. Prikhod'ko GG, Vasilyeva I, Reyes H, Wong S, Brown KE, Jameson T, et al. Evaluation of a new LightCycler reverse transcription-polymerase chain reaction infectivity assay for detection of human parvovirus B19 in dry-heat inactivation studies. Transfusion. 2005;45(6):1011-9. doi: 10.1111/j.1537-2995.2005.04393.x. [PubMed: 15935001].

52. Huangfu C, Zhao X, Lv M, Jia J, Zhu F, Wang R, et al. Inactivation of viruses during a new manufacturing process of alpha2macroglobulin from Cohn Fraction IV by dry-heat treatment. Transfusion. 2016;56(9):2274-7. doi: 10.1111/trf.13714. [PubMed: 27383449].

53. Smales CM, Pepper DS, James DC. Protein modification during antiviral heat-treatment bioprocessing of factor VIII concentrates, factor IX concentrates, and model proteins in the presence of sucrose. Biotechnol Bioeng. 2002;77(1):37-48. doi: 10.1002/bit.10161. [PubMed: 11745172].

54. Jackson RA, Mousavi Hosseini K. Phenol-phenoxyl radical equilibria by electron spin resonance: are radicals derived from tocopherol and analogues exceptionally stabilized? J Chem Soc Chem Commun. 1992(13):967-8. 
55. Blumel J, Schmidt I, Effenberger W, Seitz H, Willkommen H, Brackmann $\mathrm{HH}$, et al. Parvovirus B19 transmission by heat-treated clotting factor concentrates. Transfusion. 2002;42(11):1473-81. doi: 10.1046/j.1537-2995.2002.00221.x. [PubMed: 12421221].

56. Barrett PN, Meyer H, Wachtel I, Eibl J, Dorner F. Inactivation of hepatitis A virus in plasma products by vapor heating. Transfusion. 1997;37(2):215-20. doi: 10.1046/j.1537-2995.1997.37297203527.x. [PubMed: 9051099].

57. Neisser-Svae A, Trawnicek L, Heger A, Mehta T, Triulzi D. Five-day stability of thawed plasma: solvent/detergent-treated plasma comparable with fresh-frozen plasma and plasma frozen within 24 hours. Transfusion. 2016;56(2):404-9. doi: 10.1111/trf.13356. [PubMed: 26419404].

58. Vacante D, Connell-Crowley L. Protocol for Evaluation of Virus Inactivation Using Low-pH Treatment. PDA J Pharm Sci Technol. 2014;68(1):90-7. doi: 10.5731/pdajpst.2014.00969. [PubMed: 24504239].

59. Hsieh YT, Mullin L, Greenhalgh P, Cunningham M, Goodrich E, Shea J, et al. Single-use technology for solvent/detergent virus inactivation of industrial plasma products. Transfusion. 2016;56(6):1384-93. doi: 10.1111/trf.13619. [PubMed: 27125447]

60. Cushing MM, Asmis L, Calabia C, Rand JH, Haas T. Efficacy of solvent/detergent plasma after storage at 2-8 degrees $C$ for 5 days in comparison to other plasma products to improve factor $\mathrm{V}$ levels in factor V deficient plasma. Transfus Apher Sci. 2016;55(1):114-9. doi: 10.1016/j.transci.2016.04.015. [PubMed: 27156966].

61. Liumbruno GM, Franchini M. Solvent/detergent plasma: pharmaceutical characteristics and clinical experience. J Thromb Thrombolysis. 2015;39(1):118-28. doi: 10.1007/s11239-014-1086-1. [PubMed: 24844804].

62. Nasiri S, Rezvan H, Mousavi Hosseini K, Roostaei MH. Preparation of highly purified S/D coagulation F VII and F IX concentrate from PPSB. Med J Islam Repub Iran. 2001;15(2):103-8.

63. Rezvan H, Nasiri S, Mousavi Hosseini K, Golabi M. A study on the application and efficacy of solvent-detergent treatment in the process of purifying F VII from prothrombin complex. Med J Islam Repub Iran. 2002;16(3):179-82.

64. Chou ML, Burnouf T, Chang SP, Hung TC, Lin CC, Richardson CD, et al. TnBPTriton X-45 treatment of plasma for transfusion efficiently inactivates hepatitis C virus. PLoS One. 2015;10(2):e0117800. doi: 10.1371/journal.pone.0117800. [PubMed: 25658612].

65. Nesterova NV, Kurkina OV, Samoilenko VA, Skrynnyk MM. Physicochemical and biological properties of solvent/detergent treated immunoglobuin G preparations. Mikrobiol Z. 2009;71(6):35-42. [PubMed: 20455431].

66. Burnouf T, Goubran HA, Radosevich M, Sayed MA, Gorgy G, ElEkiaby M. A minipool process for solvent-detergent treatment of cryoprecipitate at blood centres using a disposable bag system. Vox Sang. 2006;91(1):56-62. doi: 10.1111/j.1423-0410.2006.00772.x. [PubMed: 16756602].

67. Pourmokhtar M, Dinarvand R, Mousavi Hosseini K, Rezvan H, Jalili MA. Solvent-detergent treatment of IgM-enriched immunoglobulin. DARU. 2003;11(2):47-51.

68. Horowitz B, Bonomo R, Prince AM, Chin SN, Brotman B, Shulman RW. Solvent/detergent-treated plasma: a virus-inactivated substitute for fresh frozen plasma. Blood. 1992;79(3):826-31. [PubMed: 1310064]

69. Mazzer AR, Perraud X, Halley J, O’Hara J, Bracewell DG. Protein A chromatography increases monoclonal antibody aggregation rate during subsequent low $\mathrm{pH}$ virus inactivation hold. $J$ Chromatogr A. 2015;1415:83-90. doi: 10.1016/j.chroma.2015.08.068. [PubMed 26346187].

70. Solano S, Segura A, Leon G, Gutierrez JM, Burnouf T. Low pH formulation of whole IgG antivenom: impact on quality, safety, neutralizing potency and viral inactivation. Biologicals. 2012;40(2):129-33. doi: 10.1016/j.biologicals.2011.11.006. [PubMed: 22266304].

71. Mueller M, Wan C, Hoi KM, Kim DY, Gan HT, Bardor M, et al Immunoglobulins M survive low-pH conditions used for virus inactivation and for elution from bioaffinity columns. J Pharm Sci. 2013;102(3):1125-32. doi:10.1002/jps.23428. [PubMed: 23280704].

72. She YM, Cheng K, Farnsworth A, Li X, Cyr TD. Surface modifications of influenza proteins upon virus inactivation by beta-propiolactone. Proteomics. 2013;13(23-24):3537-47. doi: 10.1002/pmic.201300096. [PubMed: 24123778].

73. Elikaei A, Sharifi Z, Hosseini SM, Latifi H, Musavi Hosseini MK. Inactivation of model viruses suspended in fresh frozen plasma using novel methylene blue based device. Iran JMicrobiol. 2014;6(1):41-5. [PubMed: 25954491].

74. Steinmann E, Gravemann U, Friesland M, Doerrbecker J, Muller $\mathrm{TH}$, Pietschmann T, et al. Two pathogen reduction technologiesmethylene blue plus light and shortwave ultraviolet lighteffectively inactivate hepatitis $\mathrm{C}$ virus in blood products. Transfusion 2013;53(5):1010-8. doi: 10.1111/j.1537-2995.2012.03858.x. [PubMed: 22905868].

75. Hornsey VS, Drummond O, Young D, Docherty A, Prowse CV. A potentially improved approach to methylene blue virus inactivation of plasma: the Maco Pharma Maco-Tronic system. Transfus Med. 2001;11(1):31-6. doi: 10.1046/j.1365-3148.2001.00282.x. [PubMed 11328569].

76. Wagner SJ, Robinette D, Storry J, Chen XY, Shumaker J, Benade L. Differential sensitivities of viruses in red cell suspensions to methylene blue photosensitization. Transfusion. 1994;34(6):521-6. doi: 10.1046/j.1537-2995.1994.34694295069.x. [PubMed: 8023394].

77. Mohr H, Lambrecht B, Selz A. Photodynamic virus inactivation of blood components. Immunol Invest. 1995;24(1-2):73-85. doi: 10.3109/08820139509062763. [PubMed: 7713607].

78. Blumel J, Rinckel LA, Lee DC, Roth NJ, Baylis SA. Inactivation and neutralization of parvovirus B19 Genotype 3. Transfusion. 2012;52(7):14907. doi: 10.1111/j.1537-2995.2012.03573.x. [PubMed: 22339291]

79. Salunkhe V, van der Meer PF, de Korte D, Seghatchian J, Gutierrez L. Development of blood transfusion product pathogen reduction treatments: a review of methods, current applications and demands. Transfus Apher Sci. 2015;52(1):19-34. doi: 10.1016/j.transci.2014.12.016. [PubMed: 25620756].

80. Devine DV, Schubert P. Pathogen Inactivation Technologies: The Advent of Pathogen-Reduced Blood Components to Reduce Blood Safety Risk. Hematol Oncol Clin North Am. 2016;30(3):609-17. doi: 10.1016/j.hoc.2016.01.005. [PubMed: 27112999]. 